\title{
Reduction of Seed Production of Red Rice Escapes in Clearfield Rice ${ }^{1}$
}

\author{
Redução da Produção de Sementes de Escapes de Plantas de Arroz-Vermelho em Arroz \\ Clearfield
}

MENEZES, V.G. ${ }^{2}$, KALSING, A. ${ }^{2}$, MARIOT, C.H.P. ${ }^{3}$, GROHS, D.S. ${ }^{3}$, and FREITAS, T.F.S. ${ }^{2}$

\begin{abstract}
Roguing is a practice used to reduce the seed source of red rice escapes to control in Clearfield-rice areas. However, there is great difficulty in performing it in large and heavily infested rice fields. This objective of this work was to evaluate the effects of the use of imazamox herbicide, applied in different rates and times, on plants of Clearfield-rice and red rice. Four experiments were conducted during the 2007/08 and 2008/09 growing seasons, in completely randomized block design and treatments arranged in factorial design, using three replications per treatment. The treatments had increasing rates of imazamox, application times and rice cultivars. The rice cultivars tested were IRGA 417, IRGA $422 \mathrm{CL}$, Avaxi CL and Puitá INTA CL. The variables evaluated were the number of panicles $\mathrm{m}^{-2}$, number of grains panicle ${ }^{-1}$, spikelet sterility in rice and red rice; and, rice grain yield and its components. The imazamox reduced the seed production of red rice escapes in a simulated situation of commercial Clearfield-rice area. The greater percentage reductions were obtained when this herbicide was applied at final formation of the panicle or panicle exertion of the red rice plant escapes to control. The Puitá INTA CL cultivar has high level of resistance to imazamox, independent of rate and application times tested, becoming the only alternative to the use of this practice.
\end{abstract}

Keywords: Oryza sativa, imazamox, roguing, resistance, prevention.

\begin{abstract}
RESUMO - O arranque manual ou roguing é uma prática utilizada para redução da produção de sementes de plantas de arroz-vermelho que escapam ao controle nas áreas de arroz Clearfield. Contudo, nas lavouras extensas ou altamente infestadas há dificuldade de realizar o controle manual dessa planta daninha devido a questões técnicas e/ou econômicas. O objetivo deste trabalho foi avaliar os efeitos do uso do herbicida imazamox, aspergido em distintas doses e épocas, sobre plantas de arroz cultivado e arroz-vermelho. Foram conduzidos, nas safras 2007/08 e 2008/09, quatro experimentos delineados em blocos ao acaso e arranjados em esquema fatorial, usando-se três repetições por tratamento. Os tratamentos constaram da combinação de doses crescentes de imazamox, épocas de aplicação e/ ou cultivares de arroz, a seguir: IRGA 417, IRGA 422 CL, Avaxi CL e Puitá INTA CL. As variáveis avaliadas foram o número de panículas $m^{-2}$, o número de grãos por panícula, a esterilidade de espiguetas de arroz cultivado e arroz-vermelho e o desempenho agronômico da cultura do arroz. O herbicida imazamox propiciou redução da produção de sementes de escapes de plantas de arroz-vermelho, em situação simuladora de área comercial de produção de arroz Clearfield. Os maiores percentuais de redução foram obtidos com as aplicações feitas nos estádios de emborrachamento do colmo ou emissão da panícula das plantas de arroz-vermelho. A prática de manejo não se adequou a todos os cultivares de arroz Clearfield testados, uma vez que apenas Puitá INTA CL não teve seu desempenho agronômico alterado pelo imazamox.
\end{abstract}

Palavras-chave: Oryza sativa, imazamox, roguing, resistência, prevenção.

1 Recebido para publicação em 31.7.2012 e aprovado em 10.11.2012.

2 Estação Experimental do Arroz, Instituto Rio Grandense do Arroz - IRGA, Cachoeirinha-RS, Brasil, <vmgaedke@yahoo.com.br>; ${ }^{3}$ Embrapa Uva e Vinho - CNPUV, Bento Gonçalves-RS, Brasil. 


\section{INTRODUCTION}

Irrigated rice (Oryza sativa) is important to the municipalities located in the southern region (subdivisions of Brazilian states) of the state of Rio Grande do Sul, for its nutrients, and environmental, economical, and social aspects. Each year, the cultivation of such grain covers an area of over one million hectares, in which about eight million tons of grain are produced (IBGE, 2012). Moreover, rice cultivation involves about 20,000 producers, employs more than 200,000 workers and generates an annual financial value of approximately R\$ 5 billion (IRGA, 2006). Thus, rice cultivation is a major source of food, money, and labor for a high percentage of farmers and workers in this region.

Over the past few years, rice cultivation in Rio Grande do Sul has reached increased yield levels, due to the use of cultivars and agronomic practices indicated by surveys (SOSBAI, 2012). Accordingly, the insertion of cultivars resistant to imidazolinones (Clearfield) is one of the main factors that allowed to optimize cultivation. The purpose of using such cultivars is to selectively control red rice (Oryza sativa), which stands out as the main weed in this crop (Menezes et al., 2009). By controlling red rice, one can employ management practices to obtain high grain yield, such as choosing the best sowing period, proper arrangement of rice plants, and fertilization for high yield (Mariot et al., 2009).

Most of the times, herbicides of the imidazolinone group can effectively control red rice plants, especially when applied during the initial stages of this weed. The use of the imazethapyr + imazapic mixture (Only $\left.{ }^{\circledR}\right)$ at a dose equivalent to $75+25 \mathrm{~g} \mathrm{ha}^{-1}$ has provided control of this weed in a rate that was always greater than 95\% (Fleck et al. 2001). In another study that was conducted to assess the herbicidal action of that same mixture on red rice, they found that control rate ranged from 98 to 99\% (Villa et al. 2006). However, even when taking precise actions, it is not always possible to get absolute control of weeds, some plants are able to escape chemical control. The presence of red rice "escapes" near cultivated rice creates opportunity to crossing and consequently to the migration of resistant genes. Recent studies indicate that the origin of resistance to imidazolinone in biotypes of red rice mainly occurs $(98.9 \%)$ via gene migration (Goulart et al., 2012).

Roguing is an agricultural practice recommended for the control of red rice plants that escape chemical control in Clearfield rice areas (SOSBAI, 2012). Roguing can be successfully performed for the control of this weed's escapes in small-sized commercial crops or with low level infestation. However, in large areas of production, or heavily infested with red rice, it is very difficult to perform manual control of plant escapes. Using imidazolinone during the escapes plant reproductive phase may reduce seed production in Clearfield rice crop areas. This practice would help reduce the reserves of weed propagules in the soil, since the treated plants would not supply soil seed bank.

The aim of this study was to assess the effects of imazamox, sprinkled in different doses and application periods on cultivated rice and red rice plants.

\section{MATERIAL AND METHODS}

The experiments were conducted in the field at the Estação Experimental do Arroz (Rice Experimental Station), at the Instituto RioGrandense do Arroz (EEA/IRGA), in the city of Cachoeirinha-RS, in the Planície Costeira Interna (Inner Coastal Plain Region). The climate in this region is humid subtropical, according to the Köppen classification, with mean temperature of 9.8 and $31.6^{\circ} \mathrm{C}$ in the coldest and warmer months, respectively. Soil in the experimental site is classified as haplic Gleysol Hapludox (Streck et al., 2008), containing $150 \mathrm{~g} \mathrm{~kg}^{-1}$ clay, $15 \mathrm{~g} \mathrm{~kg}^{-1}$ organic matter and $\mathrm{pH} 5.8$. The area has been frequently managed in soil-tillage system, with irrigated rice cultivation in the warm season and ryegrass cover in the winter season.

Four experiments were conducted, of which two during the $2007 / 08$ crop season and two in the 2008/09 season. In all four cases, conventional cropping system was used and management was based on rice cultivation practices indicated by research (SOSBAI, 2012). Rice sowing has always occurred at a 
time period considered to be appropriate (Oct/ 1st to Nov/15), with $100 \mathrm{~kg} \mathrm{ha}^{-1}$ of seed, which resulted in initial density of 350 plants $\mathrm{m}^{-2}$. Soil fertilization was made by filling $400 \mathrm{~kg} \mathrm{ha}{ }^{-1}$ rows using formula 05-20-30, which contributed to $20 \mathrm{~kg} \mathrm{ha}^{-1}$ of $\mathrm{N}, 80 \mathrm{~kg}^{-1}$ of $\mathrm{P}_{2} \mathrm{O}_{5}$ and $120 \mathrm{~kg} \mathrm{ha}^{-1}$ of $\mathrm{K}_{2} \mathrm{O}$. In addition, two doses of nitrogen fertilizer were applied to the cover: 80 and $40 \mathrm{~kg} \mathrm{ha}^{-1} \mathrm{~N}$, respectively, at growth stages $V_{4}$ and $V_{8}$ (Counce et al., 2000).

In both seasons, an experiment was conducted to evaluate the effect of treatment in the control of red rice escapes, and the other, on the performance of cultivated rice. In the first case, the experiments were conducted at a site with weed seed bank, plus the distribution of new seedlings to increase infestation. The control management of red rice was carried out with the application of a $45+15 \mathrm{~g} \mathrm{ha}^{-1}$ dose of imazethapyr+imazapic, at growth stage $V_{3}$ (Counce et al., 2000). Such dose was used to stimulate the occurrence of red rice escapes, since it was less intense than the recommended dose for the management of this species. Moreover, in all situations, cyhalofop-butyl (360 $\left.\mathrm{g} \mathrm{ha}^{-1}\right)$ and penoxsulam (48 $\mathrm{g} \mathrm{ha}^{-1}$ ) were used to help control other weeds.

In the 2007/08 harvest, experimental treatments consisted of five doses of imazamox $\left(0,21,31,42\right.$ and $\left.63 \mathrm{~g} \mathrm{ha}^{-1}\right)$ and four application periods, which amounted to phenological stages of cultivated rice or red rice plants, according to the scale of Counce et al. (2000) $\left(R_{0}, R_{1}, R_{3}\right.$ and $\left.R_{4}\right)$. The growth stages were as follows: $\mathrm{R}_{0}$ : stem elongation (ELC), $\mathrm{R}_{1}$ : panicle primordial differentiation (DPP), R3: boot stage (EBC), and R4: panicle initiation (EMP). At this season, Puita INTA CL was the cultivar used in both experiments. In the 2008/09 harvest, the experiment focused on weed control was identical to that performed in the previous season, while in the other experiment three doses of imazamox $\left(0,42\right.$ and $\left.84 \mathrm{~g} \mathrm{ha}^{-1}\right)$ were tested, as well as four cultivars of rice: IRGA 417, IRGA 422 CL, Avaxi CL and Puitá INTA CL. Clearfield (CL) cultivars are resistant to imidazolinone (SOSBAI, 2012), and IRGA $422 \mathrm{CL}$ is first generation, and Avaxi CL and Puitá INTA CL are second generation. In this experiment, treatment applications were performed when the studied plant cultivars reached growth stage $R_{3}$ (Counce et al., 2000). It is noteworthy that imazamox is not registered for rice cultivation in Brazil and has been used in this work in order to test the hypothesis under study.

In all cases, the experimental outline consisted of complete randomized blocks with treatments arranged in a factorial arrangement with three replicates per treatment. The experimental units were $7.0 \times 1.7 \mathrm{~m}$ plots, to which different combinations of treatments were randomly applied. For herbicide applications we used a precision backpack sprayer, 110.03 flat spray nozzles, distributing spray volume of $165 \mathrm{~L} \mathrm{ha}^{-1}$. This operation was always performed in periods with proper temperature (18 to $26^{\circ} \mathrm{C}$ ) and humidity (68 to $94 \%$ ) suitable for the improved activity of imazamox.

The effects of treatment combinations in both trials that focused on controlling red rice escapes were determined at harvest. On this date, we assessed in each plot the number of panicles $\mathrm{m}^{-2}$ developed, the number of panicle grains $^{-1}$ and the percentage of weed spikelet sterility. After gathering data from the first two explanatory variables, we normalized to percentage value in relation to red rice untreated control (TSC). In order to do so, we used the mean value of the plots with no imazamox application as standard reference, according to the mathematical expression described by Equation 1:

$$
Y(\%)=[(X a-X b) / X a) * 100] \quad(\text { eq. } 1)
$$

where $\mathrm{Y}$ is the normalized value relative to the TSC (\%); $X a$ is the mean value of treatment TSC, and " $X b$ ", the value of a treatment to be normalized.

Data from the three variables were analyzed as for assumptions to analysis of variance procedure, and it was found to be normalized in all situations tested. Thus, we proceeded to the combined analysis of variance among experiments (or seasons), with $5 \%$ probability of experimental error as limit to the significance. Treatment means were compared by the value of the least significant difference (LSD) of the Student $t$ test, using $5 \%$ level of significance. The variance analysis was complemented by 
different regression analyzes, adjusting response functions of variables through linear or quadratic models.

The effects of treatment combinations in both trials focusing on the performance of cultivated rice were also determined at harvest. Firstly, ten rice panicles were randomly collected in each experimental unit, with which we determined the number of panicle grains ${ }^{-1}$ and grain mean weight. Then, eight central rows of each plot were mechanically harvested, or $9.5 \mathrm{~m}^{2}$, and the number of panicles $\mathrm{m}^{-2}$ and grain yield were determined. The analysis of variance of original data gathered from each experiment was performed, under the same conditions previously described for the limit of significance. Regression analyzes were performed to estimate the effects of treatments in each rice cultivar examined, and data were adjusted to fit the linear or exponential models.

\section{RESULTS AND DISCUSSION}

\section{Experiments focusing on red rice}

The number of panicles varied as a result of interaction between season and dose $(p<0.01)$ or as a result of simple effect of imazamox time of application $(\mathrm{p}<0.05)$. It is found that this variable was reduced quadratically with increasing dose of imazamox, which differed on the two seasons (Figure 1). In general, the equivalent imazamox dose to $42 \mathrm{~g} \mathrm{ha}^{-1}$ decreased by about $60 \%$ the number of panicles, compared to untreated weed (TSC). Imazamox was more effective in reducing the emission of red rice panicles in the plots sprayed at the weed stages DPP $(40 \%)$ or EBC $(55 \%)$, compared to stages ELP (34\%) or EMP (35\% ) (not shown).

The number of grains per panicle varied according to the interaction of dose and time of application $(p<0.01)$. When application was conducted on the stages ELP or DPP, there was a linear reduction on the magnitude of this variable with increasing dose of imazamox (Figure 2). However, when applications were made during stages EBC and EMP, there was a quadratic response with increasing dose of imazamox (Table 1). In general, application on stage EBC provided greater reduction in the number of grains per panicle, compared to

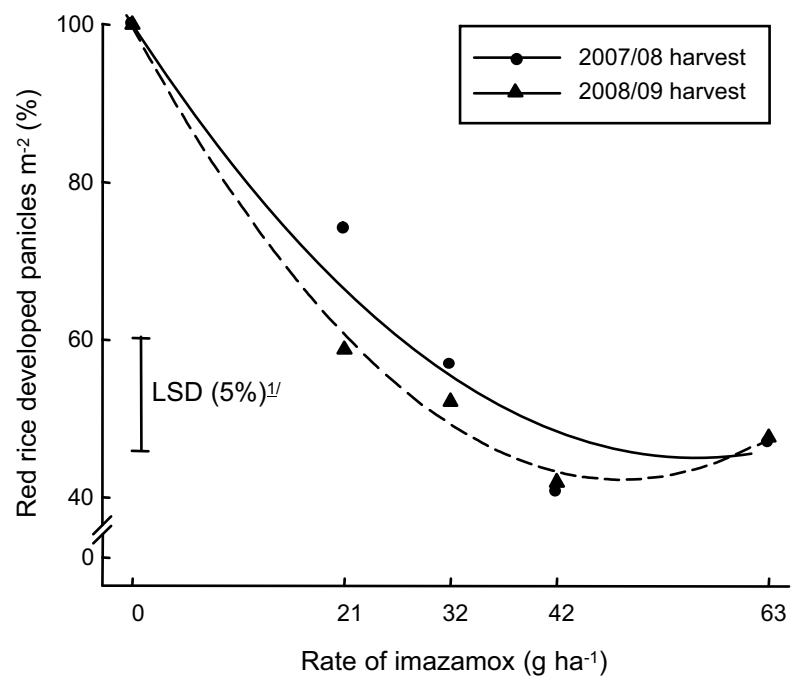

1/ Least significant difference to compare means of any treatments.

Figure 1 - Number of red rice developed panicles $\mathrm{m}^{-2}$ per doses of imazamox in percentage compared to no herbicide application, on the mean of four application times and in two seasons (2007/08 and 2008/09). Cachoeirinha, RS.

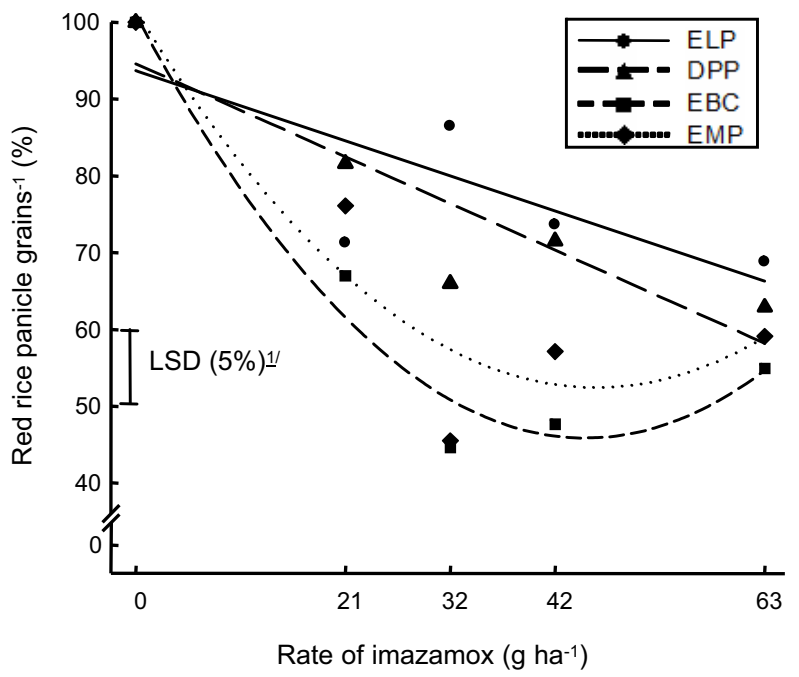

${ }^{1 /}$ Least significant difference to compare means of any treatments. ${ }^{2} 1^{\text {st }}$ period - ELC (stem elongation), $2^{\text {nd }}$ period - DPP (panicle primordial differentiation), $3^{\text {rd }}$ period - EBC (boot stage) and $4^{\text {th }}$ period - EMP (panicle initiation).

Figure 2 - Number of red rice panicle grains ${ }^{-1}$ per doses of imazamox in percentage compared to no herbicide application, on the mean of two seasons (2007/08 and 2008/ 2) and in four application times²' Cachoeirinha, RS. 
Table 1 - Values of equation parameters ${ }^{1 /}$ used to determine the effect of treatments on two variables explanatory of red rice control. Cachoeirinha, RS

\begin{tabular}{|c|c|c|c|c|c|c|}
\hline \multirow{2}{*}{ Factor } & \multirow{2}{*}{ Model } & \multicolumn{3}{|c|}{ Equation parameters $^{\underline{1}}$} & \multirow{2}{*}{$\mathrm{R}^{2 /}$} & \multirow{2}{*}{$\mathrm{F}^{3 /}$} \\
\hline & & $\mathrm{a}$ & $\mathrm{b}$ & $\mathrm{c}$ & & \\
\hline \multicolumn{7}{|c|}{ Panicles $\mathrm{m}^{-2}$} \\
\hline 2007/08 harvest & Quadratic & $0.02 \pm 0.01$ & $-2.03 \pm 0.34$ & $102.30 \pm 5.04$ & 0.77 & $40.5^{* * 4}$ \\
\hline 2008/09 harvest & Quadratic & $0.02 \pm 0.01$ & $-2.40 \pm 0.33$ & $99.70 \pm 4.91$ & 0.77 & $41.7^{* *}$ \\
\hline \multicolumn{7}{|c|}{ Panicle grains $^{-1}$} \\
\hline 1st period (ELC) $)^{\frac{5}{1}}$ & Linear & $93.70 \pm 8.06$ & $-0.44 \pm 0.22$ & --- & 0.36 & $4.2^{*}$ \\
\hline 2nd Period (DPP) & Linear & $94.60 \pm 9.24$ & $-0.62 \pm 0.24$ & --- & 0.40 & $3.2^{*}$ \\
\hline 3rd Period (EBC) & Quadratic & $0.03 \pm 0.01$ & $-2.55 \pm 0.73$ & $101.02 \pm 10.92$ & 0.60 & $7.7^{* *}$ \\
\hline 4th Period (EMP) & Quadratic & $0.02 \pm 0.01$ & $-2.10 \pm 0.71$ & $101.55 \pm 10.42$ & 0.58 & $6.7^{* *}$ \\
\hline
\end{tabular}

${ }^{1 /}$ Simple linear regression equation $[\mathrm{Y}=\mathrm{a}+\mathrm{bX}]$ and quadratic $[\mathrm{Y}=\mathrm{aX}+\mathrm{bX}+\mathrm{c}]$, where ' $\mathrm{Y}$ ' and ' $\mathrm{X}$ ' are variables and ' $\mathrm{a}$ ', ' $\mathrm{b}$ ' and ' $\mathrm{c}$ ' are the parameters of the equation. ${ }^{2 /}$ Correlation coefficient among treatments and response of variables. ${ }^{3 /}$ Value of test ' $F$ ' for the regression analysis of treatments and response of variables. ${ }^{4 /}$ Value of test ' $\mathrm{F}$ ' at $5 \%\left({ }^{*}\right)$ and $1 \%(* *)$ probability of experimental error. ${ }^{5 /} 1^{\text {st }}$ period - ELC (stem elongation), $2^{\text {nd }}$ period - DPP (panicle primordial differentiation), $3^{\text {rd }}$ period - EBC (boot stage) and $4^{\text {th }}$ period - EMP (panicle initiation).

applications in other stages. It is important to note that significant differences are not always found among equivalent doses in comparisons of applications in the development stages of the weed.

The percentage of spikelet sterility varied according to the simple effect of application time $(p<0.01)$. The plants of sprayed plots at stages EBC and EMP did not differ among themselves and overcame plants treated on stages ELC and DPP (Figure 3). In fact, the percentage of sterile spikelets was $10 \%$ higher in plants sprayed in stages EBC and EMP, compared to that where there was no application of imazamox. It is also noteworthy that there was no statistical differences among the values found for plants treated at stages ELC and DPP and untreated weed.

\section{Experiments focusing on cultivated rice}

In the 2007/08 season, with Puitá INTA $\mathrm{CL}$, no treatment effects were found for the following variables: number of panicles, number of grains per panicle, and mean grain weight. On average, 542 panicles $\mathrm{m}^{-2}$, 48 grains per panicle and $22 \mathrm{mg}$ per grain were recorded. Regarding grain yield, simple effect of application dose $(\mathrm{p}<0.01)$ was noted. In this case, there was linear decrease of this variable's magnitude as a function of increased imazamox dose on the mean of application

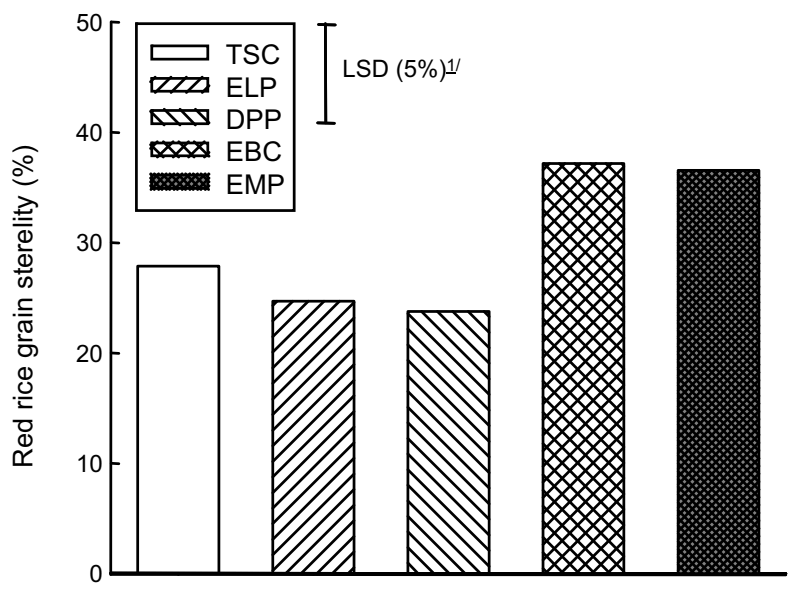

Application times of imazamox

${ }^{1 /}$ Least significant difference to compare means of any treatments. ${ }^{2} /$ TSC (untreated control), $1^{\text {st }}$ period - ELC (stem elongation), $2^{\text {nd }}$ period - DPP (panicle primordial differentiation), $3^{\text {rd }}$ period - EBC (boot stage) and $4^{\text {th }}$ period - EMP (panicle initiation).

Figure 3 - Sterelity of red rice grain by times ${ }^{2 /}$ of imazamox application, on the mean of two seasons (2007/08 and 2008/09) and five doses. Cachoeirinha, RS.

times (Figure 4). It can be estimated with the regression equation that each gram of imazamox decreased grain yield of irrigated rice by $11.5 \mathrm{~kg}$ in relation to TSC.

In the 2008/09 season that included four rice cultivars, of which three were resistant to imidazolinone, no treatment effect was 


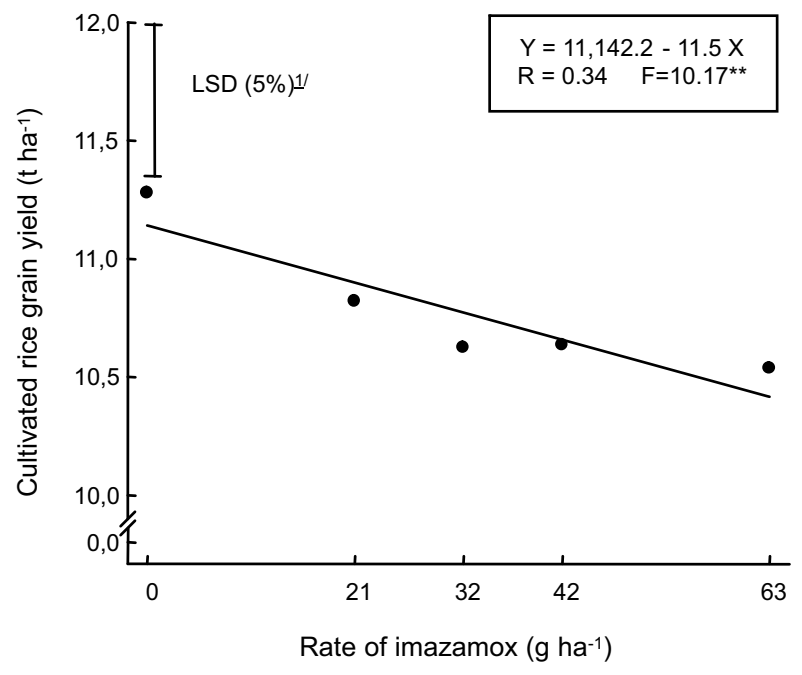

${ }^{1 /}$ Least significant difference to compare means of any treatments.

Figure 4 - Grain yield of Puitá INTA CL per doses of imazamox, on the mean of four application times on the 2007/08 season. Cachoeirinha, RS. noted for number of panicles. For the variables of number of grains per panicle, mean grain weight, grain yield, and spikelet sterility, there was interaction between cultivar and dose $(\mathrm{p}<0.01)$. In most situations, there was significant response of these four variables explanatory of crop performance to increasing doses of imazamox (Table 2). The mathematical expressions used to represent such response differed according to the rice cultivar examined (Figure 5A to 5D).

Puitá INTA CL was the only cultivar of irrigated rice that was not negatively affected by the use of imazamox, whose performance did not vary as imazamox dose increased (Table 2). For Avaxi CL, we found linear response to increasing doses of imazamox only for spikelet sterility and grain yield. As for IRGA 417 and IRGA $422 \mathrm{CL}$, there was exponential decreased with increasing dose of imazamox for number of panicle grains,

Table 2 - Values of equation parameters ${ }^{\frac{1}{}}$ used to determine the effects of treatments on variables explanatory of cultivated rice phytotoxicity, on the 2008/09 season. Cachoeirinha, RS

\begin{tabular}{|c|c|c|c|c|c|}
\hline \multirow{2}{*}{ Cultivar } & \multirow{2}{*}{ Model } & \multicolumn{2}{|c|}{ Equation parameters ${ }^{1 /}$} & \multirow{2}{*}{$\mathrm{R}^{2} /$} & \multirow{2}{*}{$\mathrm{F}^{3 /}$} \\
\hline & & $\mathrm{a}$ & $\mathrm{b}$ & & \\
\hline \multicolumn{6}{|c|}{ Panicle grains ${ }^{-1}$} \\
\hline IRGA 417 & Exponential & $78.02 \pm 1.40$ & $-0.37 \pm 0.30$ & 0.99 & $2,048.5^{* * 4}$ \\
\hline IRGA $422 \mathrm{CL}$ & Exponential & $69.12 \pm 4.84$ & $-0.05 \pm 0.02$ & 0.97 & $108.2^{* *}$ \\
\hline Avaxi CL & Linear & $66.65 \pm 10.22$ & $-0.06 \pm 0.18$ & 0.13 & $0.1^{\mathrm{ns}}$ \\
\hline Puitá INTA CL & Linear & $74.67 \pm 11.58$ & $-0.07 \pm 0.21$ & 0.12 & $0.1^{\mathrm{ns}}$ \\
\hline \multicolumn{6}{|c|}{ Grain weight } \\
\hline IRGA 417 & Exponential & $28.85 \pm 0.00$ & $-0.51 \pm 3.32$ & 0.99 & $9,542.9^{* *}$ \\
\hline IRGA $422 \mathrm{CL}$ & Exponential & $28.42 \pm 1.41$ & $-0.01 \pm 0.00$ & 0.94 & $54.1^{* *}$ \\
\hline Avaxi CL & Linear & $27.96 \pm 0.19$ & $0.00 \pm 0.00$ & 0.09 & $0.0^{\mathrm{ns}}$ \\
\hline Puitá INTA CL & Linear & $26.48 \pm 0.03$ & $0.00 \pm 0.00$ & 0.06 & $0.0^{\mathrm{ns}}$ \\
\hline \multicolumn{6}{|c|}{ Grain yield } \\
\hline IRGA 417 & Exponential & $9,314 \pm 12.64$ & $-0.44 \pm 0.85$ & 0.99 & $10,000.0^{* *}$ \\
\hline IRGA 422 CL & Exponential & $9,713 \pm 35.16$ & $-0.41 \pm 0.51$ & 0.99 & $10,000.0^{* *}$ \\
\hline Avaxi CL & Linear & $11,540 \pm 600.31$ & $-3.25 \pm 11.07$ & 0.92 & $43.5^{* *}$ \\
\hline Puitá INTA CL & Linear & $9,117 \pm 397.3$ & $-2.11 \pm 7.32$ & 0.11 & $0.1^{\mathrm{ns}}$ \\
\hline \multicolumn{6}{|c|}{ Spikelet sterility } \\
\hline IRGA 417 & Exponential & $100.00 \pm 2.26$ & $0.36 \pm 0.30$ & 0.99 & $1,144.4^{* *}$ \\
\hline IRGA $422 \mathrm{CL}$ & Exponential & $93.29 \pm 25.25$ & $0.52 \pm 1.11$ & 0.97 & $112.9^{* *}$ \\
\hline Avaxi CL & Linear & $11.54 \pm 5.82$ & $0.46 \pm 0.10$ & 0.85 & $18.2^{* *}$ \\
\hline Puitá INTA CL & Linear & $7.69 \pm 1.30$ & $0.01 \pm 0.02$ & 0.19 & $0.2^{\mathrm{ns}}$ \\
\hline
\end{tabular}

1/ Simple linear regression equation $[\mathrm{Y}=\mathrm{a}+\mathrm{bX}]$ and exponential $[\mathrm{Y}=\mathrm{ae}-\mathrm{bx}]$, where ' $\mathrm{Y}$ ' and ' $\mathrm{X}$ ' are variables and 'a', ' $\mathrm{b}$ ' and ' $\mathrm{c}$ ' are the parameters of the equation. ${ }^{2 /}$ Correlation coefficient among treatments and response of variables. ${ }^{3 /}$ Value of test ' $F$ ' for the regression analysis of treatments and response of variables. ${ }^{4 /}$ Value of test 'F' non-significant (ns) and significant at $1 \%{ }^{* *}$ probability of experimental error. 
(A)

(B)
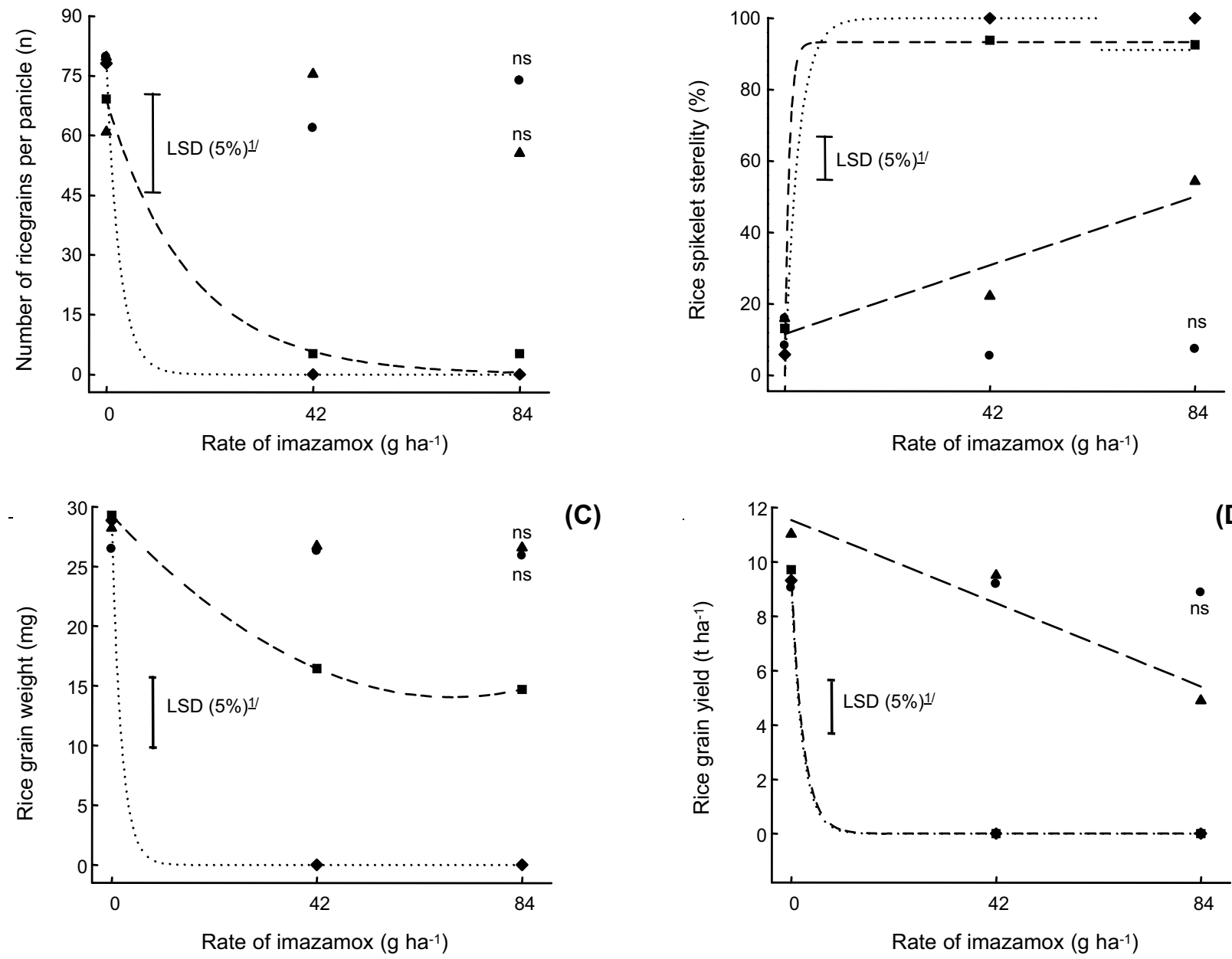

(C)

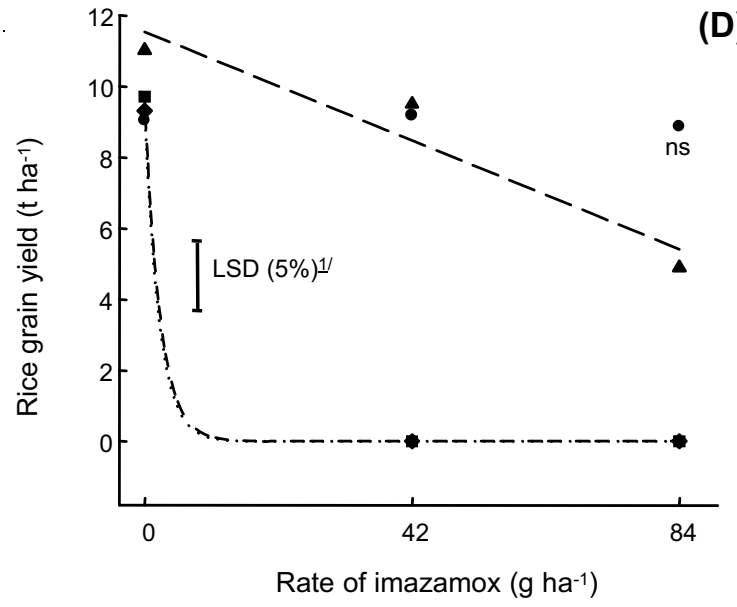

Puitá INTA CL - - - A Avaxi CL

IRGA $422 \mathrm{CL} \quad--$ IRGA 417

1/ Least significant difference to compare means of any treatments.

Figure 5 - Number of grains per panicle (A), spikelet sterility (B), grain weight (C), and grain yield (D) of four rice cultivars per rate of imazamox, in the 2008/09 season. Cachoeirinha, RS.

grain weight, and grain yield. In the case of spikelet sterility, the opposite occurred for the same cultivars, i.e. exponential increase with increasing dose. Thus, the agronomic performance of IRGA 417, IRGA 422CL, and Avaxi CL was negatively affected by the use of any dose of imazamox (Figure 5A to 5D).

\section{Combined discussion of the results of four experiments}

Our hypothesis in this study was that the application of imazamox on escapes of red rice plants would reduce seed production in areas with Clearfield rice. This would occur because the activity of this herbicide would affect the normal development of seeds during the reproductive phase, decreasing its production and/or feasibility. This management practice would limit the emergence of populations resistant to imidazolinone by hindering the occurrence of gene migration between cultivated plants and weeds. In addition, propagule reserves in the soil would gradually reduce each season, once treated escapes would not supply soil seed bank. 
The results of the experiments that focused on weed control confirmed that the application of imazamox reduced the prolificacy of red rice plants. In fact, there was considerable reduction in the number of developed panicles and in the number of grains per panicle with the use of imazamox (Figures 1 and 2). In addition, there was increased spikelet sterility of red rice in relation to TSC, in applications at stages EBC and EMP (Figure 4). These results come from the pooled analysis of two experiments conducted in two different seasons, which most certainly validates the hypothesis tested herein.

In other surveys there was also reduced seed production of red rice escapes with imidazolinone applied during the crop reproductive phase. For instance, the application of increasing doses from 280 to $840 \mathrm{~g} \mathrm{ha}^{-1}$ of imazamox at DPP provided absolute control of weed species (Meins et al., 2003). In this case, unlike this present study, they aimed to control only red rice, whose values were not statistically different among the studied doses. In another study, it was found that doses from 70 to $100 \mathrm{~g} \mathrm{ha}^{-1}$ of imazethapyr at stages DPP and EBC reduced prolificacy of red rice (Dunand et al., 2005). According to these authors, the number of panicles, grains per panicle, and spikelet sterility decreased with these treatments.

Imazamox and imazethapyr can inhibit acetolactate synthase activity and, consequently, the synthesis of branched chain amino acids valine, leucine and isoleucine (Zhou et al., 2007). It is known that such products have physical and chemical characteristics that allow for speedy absorption by plant cuticle and both apoplastic and symplastic translocation. However, the analysis of these characteristics suggest that imazamox $\left(\mathrm{pk}_{\mathrm{a}}=3.3 ; \mathrm{K}_{\mathrm{ow}}=5.4\right)$ has greater mobility through cells than imazethapyr $\left(\mathrm{pk}_{\mathrm{a}}=3.9 ; \mathrm{K}_{\mathrm{ow}}=11.0\right)$. Moreover, the same analysis indicates that imazamox has less potential to persist in the soil of subsequent crop compared to imazethapyr (Vencill, 2002). Thus, it is consistent to consider that the use of imazamox to control red rice escapes brings more benefits than the use of imazethapyr for the same purpose.

The analysis of other studies described in the literature confirms that the hypothesis proposed in this work can also be valid for other herbicides, not only for imidazolinones. For instance, the application of fluazifop and quizalofop in stage EMP has reduced red rice seed yield and feasibility (Salzman et al., 1988). In another study, the use of glyphosate, glufosinate and paraquat during physiological maturation has shown to suppress the prolificacy of weeds (Agostinetto et al. 2002). It should be noted, however, that these herbicides have no selective action and record for irrigated rice and were evaluated only for the purpose of research.

In this study, time of application of imazamox has affected the number of panicles, number of grains per panicle, and spikelet sterility (Figures 2 and 3 ). In general, greater inhibition in applications was noted for stages EBC and EMP of red rice, with regard to applications that occurred at stages ELC and DPP. This means that, after the last application, large visual differences had been observed in imazamox effect among the four seasons for number of panicles. But over time, some plants treated in EMP and DPP had reissued new panicles, reaching higher values than those of TSC. This fact may have contributed to the high coefficient of variation of the variable $(23.4 \%)$, limiting the detection of significant interaction between 'dose' and 'time' application.

There are at least two different reasons to speculate why red rice plants produced fewer seedlings when treated with imazamox at later times. Firstly, weed may have had lower metabolizing of herbicide (Saari et al., 1994), due to a shorter period of time between application and cellular differentiation. This fact would determine increased number of imazamox intact molecules acting close to their site of action in the cells of weed reproductive tissues. Secondly, it is possible that there was greater translocation of the herbicide to meristems (Trezzi \& Vidal, 2001), as a function of the flow of assimilates in the plant during the reproductive phase. As a result, it would be easier for molecules of imazamox to reach embryo cells, causing irreversible injuries in the propagule formation.

In treatment TSC, we noted that in the mean of the two experiments 90 panicles $\mathrm{m}^{-2}$ 
of red rice developed, with 70 feasible seed panicle $^{-1}$, resulting in 6,300 feasible seeds $\mathrm{m}$ ${ }^{2}$. When imazamox was applied, the number of panicles was reduced by $60 \%$ and the number of grains per panicle by up to $50 \%$, resulting in 1,156 feasible seeds $\mathrm{m}^{-2}$. Thus, imazamox may have been able to decrease by $80 \%$ the production of feasible red rice seeds when applied in the reproductive phase. This shows that chemical suppression of red rice seed production is possible in rice growing areas using Clearfield rice cultivars.

Once the hypothesis of this study had been justified, we sought to determine which varieties of rice resistant to imidazolinone would be best suited for the treatment of red rice using imazamox. To this end, experiments were conducted with focus on phytotoxicity and crop performance, where there was distinction on the response of cultivars (Figures 5A, D). In summary, our data showed that cultivars IRGA 417, IRGA $422 \mathrm{CL}$, and Avaxi CL are sensitive to imazamox application (Table 2). This shows that the management practice does not fit any Clearfield rice cultivar, and that great rice yield reduction may occur. Cultivar Puitá INTA CL was the only to have actually resisted the application of imazamox, with no significant decrease in agronomic performance (Figures 5A, D).

Rice cultivar results found in this work agree with those reported by Bond \& Walker (2011), who noted different response of rice cultivars to imazamox. In this study, it was found that one cultivar had its strength level increased and two cultivars had it decreased, when treated with doses from 44 to $88 \mathrm{~g} \mathrm{ha}^{-1}$ of imazamox. In another study, in which the response of rice cultivars to imazethapyr+ imazapic was assessed, strength level of plants differed (Roso et al., 2010a). They found, for example, that cultivars IRGA 422CL and Puitá INTA CL were up to eight and 28 times more resistant to this herbicide, compared to IRGA 417, respectively.

Rice cultivars resistant to imidazolinone present alterations in the location of action of these herbicides with the acetolactate synthase (Tan et al., 2005). Such alterations are associated with induced mutations in the gene encoding that enzyme, which can occur in different amino acids that comprise this gene (Roso et al. 2010b). According to these authors, resistance of cultivars IRGA $422 \mathrm{CL}$ and Puitá INTA CL is due to mutation in the respective positions of the acetolactate synthase gene: $A_{122} T$ and $G_{654} E$. Thus, imidazolinone's loss of connection with the site of action differs among these cultivars due to the conformation of the enzyme in each mutation. This leads to different resistance levels of rice cultivars to herbicides from such chemical group, similar to the results obtained in this present study.

Clearfield rice brought great contribution to rice cropping systems in Rio Grande do Sul, in particular, for allowing the selective control of red rice. In order for the benefits of this technology to avail for long periods of time, each harvest needs to have their weeds treated. This management practice prevents the occurrence of crosses between cultivated rice and red ruce, narrowing the selection of specimens resistant to imidazolinone. Moreover, by controlling red rice, you are providing a gradual decrease in its seed bank, and thereby reducing site infestation over time. Thus, it becomes essential to use control techniques for red rice escapes in crop areas, in particular on those that use Clearfield cultivars.

Imazamox has not been approved for use in irrigated rice in Brazil and therefore can not be used to control red rice escapes. There are currently other imidazolinone with authorization for use on this crop (Brasil, 2012), which are being widely used by farmers for this purpose. It is noteworthy that, to succeed in reducing the prolificacy of red rice by chemical use, all practices listed in the research should be used (SOSBAI, 2012). These practices mainly include the use of certified seed, the use of herbicide before and after crop emergence, time of irrigation and crop rotation. Otherwise, the benefits of weed chemical control will be lost over time and, after successive seasons, the selection of red rice biotypes resistant to imidazolinone may occur. This side effect implies that one should be aware that only by integrating all available techniques it will be possible to manage red rice in a sustainable manner.

This present work has shown, based on results obtained and discussed, that imazamox 
has reduced red rice escapes seed production in a simulated situation on a commercial area of Clearfield rice production. Imazamox time of application for red rice stages EBC and EMP resulted in higher levels of weed prolificacy suppression. This management practice did not fit all Clearfield rice cultivars tested, only Puitá INTA CL ( $2^{\text {nd }}$ generation) showed high level of resistance to imazamox and did not have their agronomic performance affected.

\section{LITERATURE CITED}

AGOSTINETTO, D. et al. Supressão da produção de sementes de arroz-vermelho pela aplicação de herbicidas em arroz irrigado. Pesq. Agropec. Bras., v. 37, n. 1, p. 57-65, 2002.

BRASIL. Ministério da Agricultura, Pecuária e Abastecimento. Sistema de Agrotóxicos Fitossanitários (Agrofit). Disponivel em: <http://extranet.agricultura.gov.br/agrofit_cons/ principal_agrofit_cons $>$. Acesso em: $1^{0}$ jun. 2012.

BOND, J. A.; WALKER, T. W. Differential tolerance of clearfield rice cultivars to imazamox. Weed Technol., v. 25, n. 1, p. 192-197, 2011.

COUNCE, P. A.; KEISLING, T. C. A uniform, objective, and adaptive system for expressing rice development. Crop Sci., v. 40, n. 2, p. 436-443, 2000.

DUNAND, R. T. et al. Reducing the potential for herbicideresistant red rice. Louisiana Agric., v. 48, n. 3, p. 9-10, 2005.

FLECK, N. G. et al. Controle químico seletivo de arrozvermelho e de capim arroz em arroz irrigado utilizando o sistema clearfield. In: CONGRESSO BRASILEIRO DE ARROZ IRRIGADO, 7., 2001, Porto Alegre. Anais... Porto Alegre: IRGA, 2001. p. 494-496.

GOULART, I. C. G. R. et al. Identification of origin and analysis of population structure of field-selected imidazolinone-herbicide resistant red rice (Oryza sativa). Euphytica, v. 182, n. 3, p. 437-447, 2012.

\section{INSTITUTO BRASILEIRO DE GEOGRAFIA E} ESTATÍSTICA - IBGE. Banco de Dados Agropecuários 2012. Disponível em: <http://www.sidra.ibge.gov.br/bda/>. Acesso em: 6 dez. 2012.

INSTITUTO RIO GRANDENSE DO ARROZ IRGA. Censo da lavoura de arroz irrigado do Rio Grande do Sul: safra 2004/2005. Porto Alegre: 2006. 122 p.
MARIOT, C. H. P. et al. Práticas integradas para a produção de arroz irrigado. Pesq. Agropec. Bras., v. 44, n. 3, p. 243-250, 2009.

MEINS, K. B. et al. Tolerance of clearfield rice to imazamox. B. R. Wells Rice Research Studies. Fayetteville: University of Arkansas Agricultural Experiment Station Report, 2003. p. 132-136.

MENEZES, V. G. et al. Arroz-vermelho (Oryza sativa) resistente aos herbicidas imidazolinonas. Planta Daninha, v. 27, p. 1047-1052, 2009. (Número Especial)

ROSO, A. C. et al. Bioensaios para diagnóstico da resistência aos herbicidas imidazolinonas em arroz. Planta Daninha, v. 28, n. 2, p. 411-419, 2010a.

ROSO, A. C. et al. Regional scale distribution of imidazolinone herbicide-resistant alleles in red rice (Oryza sativa L.) determined through SNP markers.

Field Crops Res., v. 119, n. 2, p. 175-182, 2010 b.

SAARI, L. L. et al. Resistance to acetolactate synthase inhibiting herbicides. In: POWLES, S. B.; HOLTUM, J. A. M. (Org). Herbicide resistance in plants: biology and biochemistry. Boca Raton: Lewis, 1994. p. 83-139.

SALZMAN, F. P. et al. Suppression of red rice (Oryza sativa) seed production with fluazifop and quizalofop. Weed Sci., v. 36, n. 6, p. 800-803, 1988.

STRECK, E. V. et al. Solos do Rio Grande do Sul. Porto Alegre: Emater/RS - UFRGS, 2008. 222 p.

SOCIEDADE SUL-BRASILEIRA DE ARROZ IRRIGADO - SOSBAI. Arroz irrigado: recomendações técnicas da pesquisa para o Sul do Brasil. Itajaí: SOSBAI, 2012. 177 p.

TREZZI, M. M.; VIDAL, R. A. Herbicidas inibidores da ALS. In: VIDAL, R. A.; MEROTTO JR., A. Herbicidologia. Porto Alegre: Evangraf, 2001. 152 p.

VENCILL, W. D. Herbicide handbook. 8.ed. Lawrence: Weed Science Society of America, 2002. 493 p.

VILLA, S. C. C. et al. Controle de arroz-vermelho em dois cultivares de arroz (Oryza sativa) tolerantes a herbicidas do grupo das imidazolinonas. Planta Daninha, v. 24, n. 3, p. 549-555, 2006.

ZHOU, Q. et al. Action mechanisms of acetolactate synthaseinhibiting herbicides. Pestic. Biochem. Physiol., v. 89, n. 1, p. 89-96, 2007. 